\title{
AUTHOR INDEX VOLUME 6 (1988)
}

(The issue number is given in front of the page numbers)

Clark, A.J., Education and training for librarianship and information work: Annual bibliography, 1987

Cronin, B., see L. Davenport

(3) $257-314$

(1) $61-70$

Davenport, L. and B. Cronin, Demand and supply in information work

(1) $61-70$

Day, J.M. and K. O'Donovan, Online education and marketing: A joint approach

Day, J.M., CD-ROM - An online training tool?

(3) $315-322$

(4) $403-410$

Dou, H., L. Quoniam and P. Hassanaly, Teaching bibliometric analysis and MS/DOS commands

(4) $411-423$

Ellis, D., see N. Roberts

(1) $27-37$

Farrow, C., Library and information science education in the Netherlands: The undergraduate programme

(2) 199-209

Farrow, J.F., see J.E. Rowley

(1) $71-82$

Hassanaly, P., see H. Dou

Hepworth, J.B., Database teaching in the information storage and retrieval syllabus

Khoo, S.M., The MLIS programme at the Institute for Advanced Studies, University of Malaya

(4) 393-401

Lim, E.H.T., USM/IDRC regional training course on library automation, The CDS/ISIS training course on library automation

(2) $213-216$

McGarry, K., The applied social science modular scheme: BSc in information and communication studies: 1988

(4) $425-430$

Martin, G., Data display panel: The Elf DD-1000

(2) 211-212

Massisimo, A. and M.C. Mayol, The educational framework for information professionals in Spain: A proposal and some suggestions

Mayol, M.C., see A. Massisimo

(4) $375-392$

(4) $375-392$

0167-8329/88/\$3.50 @ 1988, Elsevier. Science Publishers B.V. (North-Holland) 
Nassimbeni, M., The imperative for change: Curriculum revision in South Africa

(2) $153-185$

Nzotta, B.C., Research and education for research in Nigerian library schools

(2) $123-143$

O'Donovan, K., see J.M. Day

(3) $315-322$

Onadiran, G.T., Reactions of past students to the Bachelor of Library Science degree of Ahmadu Bello University, Zaria, Nigeria

Oulton, A.J., see J.E. Rowley

(1) $39-59$

(1) $71-82$

Paul, D., Reference and information work in local history: Training for librarians

(3) $323-338$

Quoniam, L., see H. Dou

(4) $411-423$

Roberts, N., T.D. Wilson and D. Ellis, Business information courses: A consideration of requirements

(1) $27-37$

Rowley, J.E., J.F. Farrow, A.J. Oulton and A.J. Wood, The use of INFO, a database management system, in teaching Library and Information Studies at Manchester Polytechnic (Software Section)

(1) $71-82$

Turner, J.R., Teaching conservation

(2) $145-151$

Wilson, T.D., see N. Roberts

(1) $27-37$

Wood, A.J., see J.E. Rowley

(1) $71-82$ 